\title{
Euphausiacea diversity in a trans-oceanic transect through the South Atlantic Ocean: the first Atlantic record of Thysanopoda astylata Brinton, 1975
}

\author{
ERIK MUXAGATA ${ }^{1}$, CARLA N. BARBOSA ${ }^{1}$ and VANESSA O. AGOSTINI ${ }^{2}$ \\ ${ }^{1}$ Laboratório de Zooplâncton, Instituto de Oceanografia, Universidade Federal do Rio Grande, Caixa \\ Postal 474, Avenida Itália, Km 8, Campus Carreiros, 96203-900 Rio Grande, RS, Brazil \\ ${ }^{2}$ Programa de Pós-Graduação em Oceanografia Física, Química e Geológica/PPGOFQG, Instituto de Oceanografia, Universidade \\ Federal do Rio Grande, Caixa Postal 474, Avenida Itália, Km 8, Campus Carreiros, 96203-900 Rio Grande, RS, Brazil \\ Manuscript received on January 11, 2018; accepted for publication on May 8, 2018
}

\begin{abstract}
How to cite: MUXAGATA E, BARBOSA CN AND AGOSTINI VO. 2019. Euphausiacea diversity in a trans-oceanic transect through the South Atlantic Ocean: the first Atlantic record of Thysanopoda astylata Brinton, 1975 . An Acad Bras Cienc 91: e20180034. DOI 10.1590/0001-3765201920180034.
\end{abstract}

\begin{abstract}
Information about euphausiids in central South Atlantic Ocean is scarce; hence, we investigated species composition and distribution of euphausiids along a longitudinal transect in this region, with an emphasis on Thysanopoda. Zooplankton samples were collected from 44 stations during the first Transatlantic Commission (Brazil-Africa). Euphausiids comprised 21,390 individuals across larval stages (nauplius, calyptopis, and furcilia) and adults. Furcilia and adults were classified to species level when possible, with a total of 19 identified species. Overall, Euphausia species frequency of occurrence and abundance were highest in samples collected near the African coast, while Thysanopada species dominated near the Brazilian coast. Of the euphausiids caught, 158 were identified as Thysanopoda, including 2 specimens of T. astylata, 6 T. aequalis, 3 T. pectinata, 2 T. monacantha, 2 T. tricuspida, and 1 T. egregia; 118 damaged specimens could only be identified as Thysanopoda spp., and 24 as T. aequalis / T. astylata complex because of the lack of diagnostic structures. Thysanopada egregia was present in samples collected down to $96 \mathrm{~m}$, which increases the vertical range for this species. This report constitutes the first record of Thysanopoda astylata Brinton, 1975 in Atlantic waters.
\end{abstract}

Key words: euphausiids, South Atlantic, Thysanopoda astylata, zooplankton.

\section{INTRODUCTION}

Most of our knowledge about the biology and distribution of the 60 known species of euphausiids in the South Atlantic (Gibbons et al. 1999) is based on studies of Euphausia superba Dana, 1850, which were mainly conducted near Antarctica (Brinton and Antezana 1984, Montú and Oliveira

Correspondence to: Erik Muxagata

E-mail: e.muxagata@gmail.com

ORCid: https://orcid.org/0000-0002-4210-5252
1986, Montú and Cordeiro 1986, Endo et al. 1986, Montú et al. 1994, Siegel 2015), or studies of euphausiids on the continental shelves of South America and Africa (Ramirez 1971, Montú 1977, 1982, Antezana and Brinton 1981, Lansac-Tôha 1981, Barange 1990, Curtolo et al. 1990, Barange et al. 1991, 1992, Freire 1991, Gibbons et al. 1995, Gibbons 1997, Gorri 1995, Menezes 2007, Werner 2012). There is little or no information about the biodiversity and biology of these organisms in the central regions of the Atlantic Ocean (Letessier 
et al. 2009, 2011), especially in the central South Atlantic, probably due to the scarce scientific exploration in this region compared to that in the Pacific and North Atlantic Oceans (Mauchline 1980, Gibbons et al. 1999).

Euphausia is the most-studied genus of euphausiids due to the distribution, abundance, and ecological role of its species (Brinton and Antezana 1984, Endo et al. 1986, Pillar et al. 1989, Barange and Pillar 1992, Siegel 2015, Siegel and Watkins 2016); however, even with lower abundances Thysanopoda can play a significant ecological role (e.g., pelagic-benthic coupling, biological pump) (Schnetzer and Steinberg 2002). There are 14 known species in the genus Thysanopoda (Mikkelsen 1987, Baker et al. 1990, Brinton et al. 1999); nevertheless, T. astylata Brinton 1975, T. minyops Brinton 1987, and T. spinicaudata Brinton 1953 are still unreported in South Atlantic waters (Brinton et al. 1999), which could be associated with the scarcity of studies in this region.

This study aimed to investigate the composition and distribution of euphausiids in the upper layer (22-130 m) of the South Atlantic Ocean across a longitudinal transect profile at $30^{\circ} \mathrm{S}$, with an emphasis on Thysanopoda species.

\section{MATERIALS AND METHODS}

The first cruise of the Transatlantic Commission (Brazil-Africa) (https://www.naval.com.br/ngb/C/ $\mathrm{C} 125 / \mathrm{C} 125 . \mathrm{htm})$ was carried out during the spring of 2009 (October-November) on board the Brazilian Navy ship Cruzeiro do Sul. A longitudinal transect was made in the central region of the South Atlantic Ocean at $30^{\circ} \mathrm{S}$, beginning with station 31 over the Rio Grande Rise (RGR) off the Brazilian continental shelf $\left(33^{\circ} 48^{\prime} \mathrm{W}\right)$ and ending at station 86 off the coast of South Africa (16 $46^{\circ}$ E) (Figure 1).

A total of 56 oceanographic stations were visited, and zooplankton samples were taken at 44 of them using oblique tows down to an average depth of $66 \mathrm{~m}(22-130 \mathrm{~m})$ using a 60 $\mathrm{cm}$ diameter zooplankton net with $140-\mu \mathrm{m}$ mesh size that filtered $295 \mathrm{~m}^{3}$ on average per tow (see Supplementary Material - Table SI). A calibrated flowmeter (GO2030R) was attached to the mouth of the net. Temperature profiles were obtained using a CTD (Seabird - SBE 25) that was lowered down to $200 \mathrm{~m}$ on average $(110-250 \mathrm{~m})$ or $\sim 10$ $20 \mathrm{~m}$ from the bottom on shallower casts at shelf locations. Averaged CTD data for the first 3 meters were used as surface values for each oceanographic station and plotted using ArcGIS 10.4. Zooplankton samples were most often (51.5\%) collected at night (18:00-05:59 h), while $48.5 \%$ of the samples were collected during the day (06:00-17:59 h). Due to weather conditions, all activities at sampling stations 59, 64, 76, 78, 80, and 82 were aborted.

Samples were immediately preserved in 1-L jars with $100 \mathrm{~mL}$ of $40 \%$ formaldehyde neutralized with borax for fixation at $4 \%$ strength when full (Steedman 1976). In the laboratory, all euphausiids were manually picked from the samples, counted, and staged. Undamaged adults and furcilia were identified to the lowest possible taxonomic level based on Brinton (1962, 1975), Mauchline and Fisher (1969), Mauchline (1971, 1980, 1984), Antezana and Brinton (1981), Baker et al. (1990), Brinton et al. (1999, 2013), Gibbons et al. (1999), and Martin and Davis (2001). No attempt was made to identify nauplius and calyptopis stages to species.

Euphausiacea compositions (taxa with at least two observations) were ordered using Non-Metric Multidimensional Scaling (MDS) and a Bray-Curtis similarity matrix after double standardization (function dcontand of $\mathrm{R}$ software vegan package) of the environmental variables. PERMANOVA analyses tested the statistical differences between groups of sampling stations and between day and night samples. Redundancy analysis (RDA) (adespatial package of R software) was used to extract and summarize the variations 


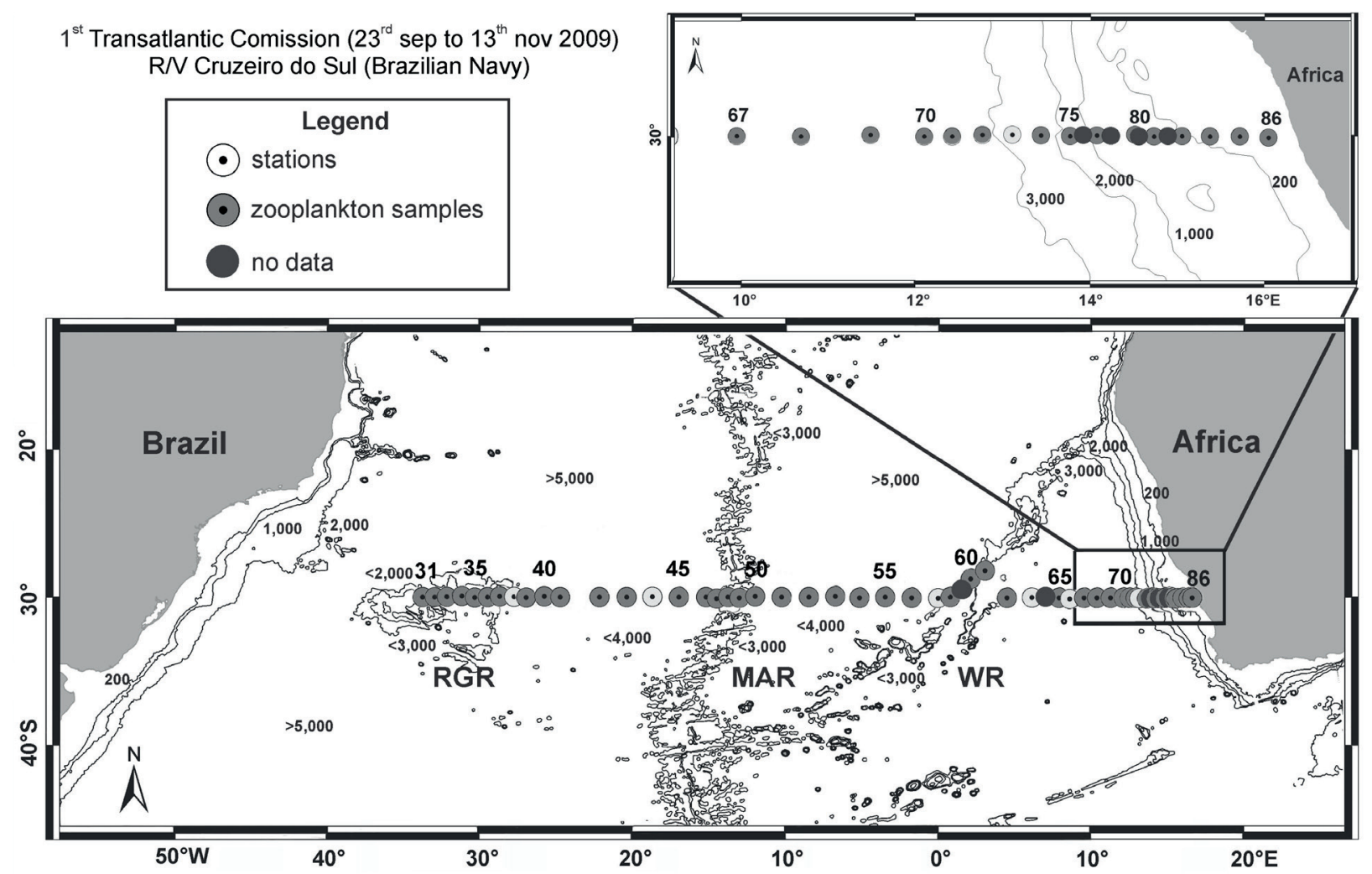

Figure 1 - Study transect through the South Atlantic Ocean at $30{ }^{\circ} \mathrm{S}$ with the 56 oceanographic stations. Bathymetry and oceanic rises are also indicated. Where: Rio Grande Rise (RGR), Mid-Atlantic Ridge (MAR), and Walvis Ridge (WR).

in the Euphausiacea composition with changes in different environmental variables (chlorophyll- $a$, temperature, salinity, and sampling depth) and euphausiid ordination was performed to observe any patterns in the composition and/or distribution of each euphausiid taxa as well as groups of taxa. The Similarity Percentage test (SIMPER) was employed to estimate the contribution (CI) of each taxon to the differences observed.

\section{RESULTS}

Surface temperature data showed higher temperatures westward from Walvis Ridge (near Brazil) with a decrease towards the eastern part of the transect (near Africa) where the shallower depths were recorded (see Figure S1). The highest temperature was observed in the central Atlantic
(20.8 ${ }^{\circ} \mathrm{C}$ at station 51), while the lowest temperature was over the African shelf $\left(16.6^{\circ} \mathrm{C}\right.$ at station 86$)$.

Of the 21,390 euphausiids found in the samples, 711 specimens were classified as nauplius, 3,937 as calyptopis, 13,586 as furcilia, and 3,156 as adults. The stage contribution analysis for each station showed that furcilia was the most abundant stage $(64 \%)$ followed by calyptopis $(17 \%)$, adults (15\%), and nauplius (4\%) (Figure 2a). Among the 30 euphausiid taxa found, 19 species belonging to six genera were identified (Figure 2b, Table I).

Overall, euphausiid abundance averaged 264.2 organisms $100 \mathrm{~m}^{-3}$ and was highest near Africa, especially over the African shelf (stations 81 to 86 ), where the average was $1,056.0$ organisms $100 \mathrm{~m}^{-3}$ with a maximum of $1,368.3$ organisms $100 \mathrm{~m}^{-3}$ (Figure 2c). Significant differences in species composition were also seen between 
a

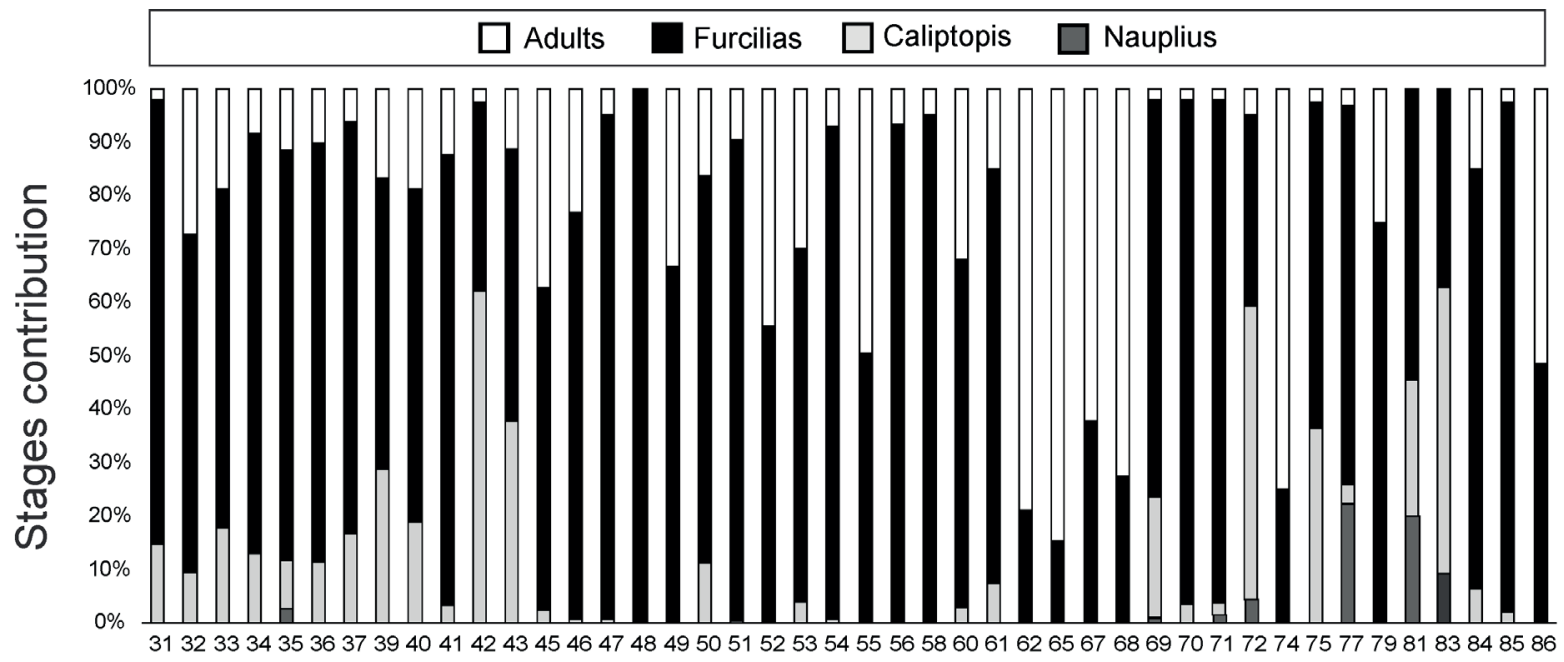

b

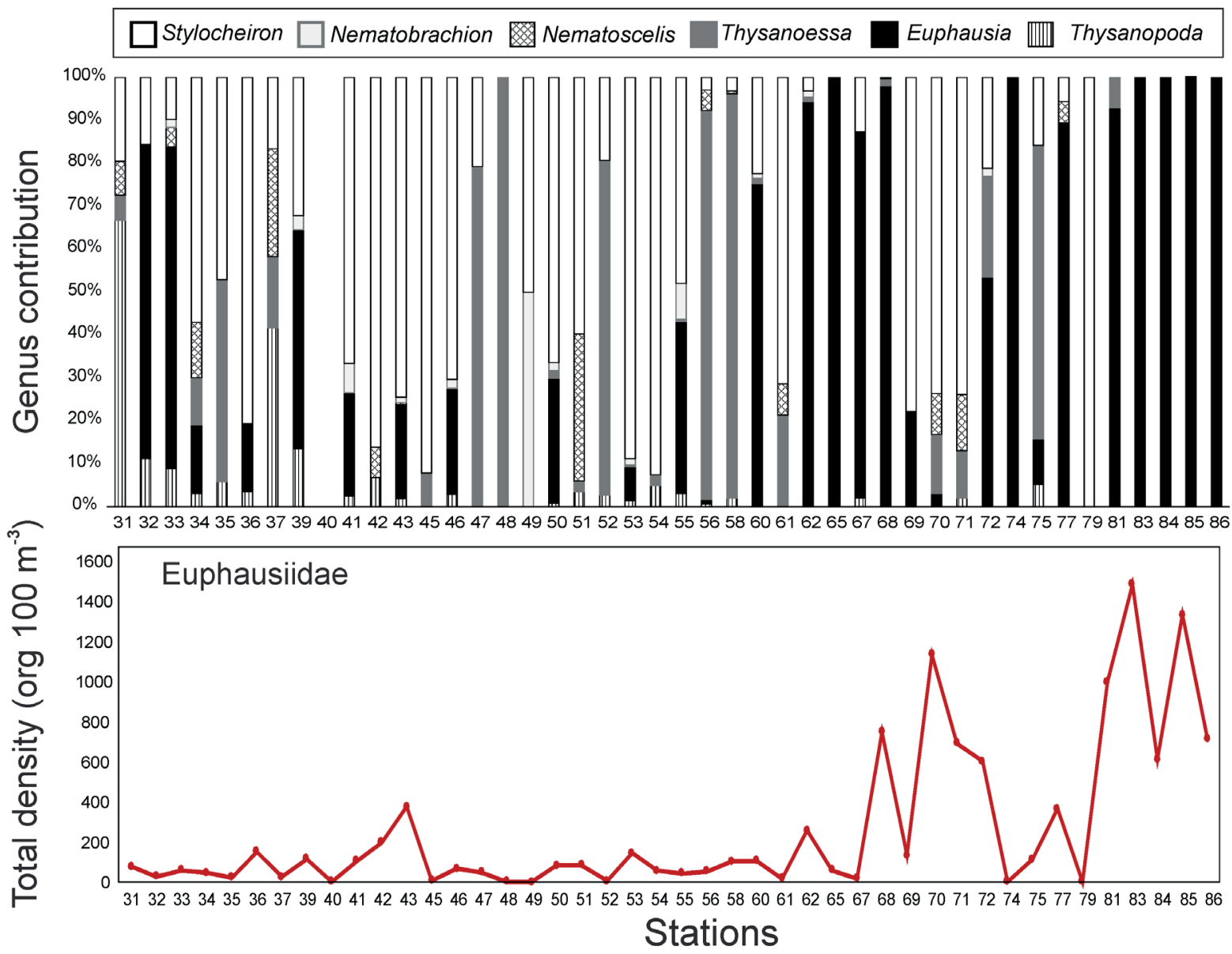

Figure 2 - (a) Percentage contribution of each euphausiid stage; (b) percentage contribution of each euphausiid genus and; (c) euphausiid total density (organisms $100 \mathrm{~m}^{-3}$ ) at each station along the $30^{\circ} \mathrm{S}$ transect through the South Atlantic Ocean. 
TABLE I

List of euphausiid taxa recorded along the $30^{\circ} \mathrm{S}$ transect through the South Atlantic Ocean during the First Transatlantic Commission (Brazil/Africa) in 2009 with the mean abundance (organisms $100 \mathrm{~m}^{-3}$ ), relative abundance (RA) and frequency of occurrence (FO).

\begin{tabular}{|c|c|c|c|}
\hline \multicolumn{4}{|l|}{ Subphylum Crustacea } \\
\hline \multicolumn{4}{|l|}{ Class Malacostraca } \\
\hline Superorder Eucarida & Mean abundance & RA $(\%)$ & $\mathrm{FO}(\%)$ \\
\hline Nauplii not id & 10.643 & 4.029 & 15.91 \\
\hline Calyptopis not id & 45.771 & 17.324 & 72.73 \\
\hline Furcilia not id & 113.744 & 43.052 & 90.91 \\
\hline Adults not id & 0.456 & 0.173 & 31.82 \\
\hline \multicolumn{4}{|l|}{ Family Euphausiidae Holt and Tattersall, 1905} \\
\hline Thysanopoda monacantha Ortmann, 1893 & 0.011 & 0.004 & 4.55 \\
\hline Thysanopoda tricuspida H. Milne Edwards, 1837 & 0.009 & 0.003 & 2.27 \\
\hline Thysanopoda astylata Brinton, 1975 & 0.013 & 0.005 & 4.55 \\
\hline Thysanopoda aequalis Hansen, 1905 & 0.034 & 0.012 & 9.09 \\
\hline Thysanopoda aequalis/astylata complex & 0.127 & 0.048 & 13.64 \\
\hline Thysanopoda pectinata Ortmann, 1893 & 0.060 & 0.023 & 6.82 \\
\hline Thysanopoda egregia Hansen, 1905 & 0.011 & 0.004 & 2.27 \\
\hline Thysanopoda spp. & 0.796 & 0.301 & 36.36 \\
\hline Euphausia mutica Hansen, 1905 & 0.114 & 0.043 & 11.36 \\
\hline Euphausia diomedeae Ortmann, 1894 & 0.909 & 0.344 & 15.91 \\
\hline Euphausia recurva Hansen, 1905 & 20.995 & 7.947 & 43.18 \\
\hline Euphausia lucens Hansen, 1905 & 49.515 & 18.741 & 25.00 \\
\hline Euphausia similis G.O. Sars, 1883 & 0.398 & 0.150 & 6.82 \\
\hline Euphausia longirostris Hansen, 1908 & 0.404 & 0.153 & 13.64 \\
\hline Euphausia spp. (gibba group) & 0.755 & 0.286 & 25.00 \\
\hline Euphausia spp. & 4.513 & 1.708 & 34.09 \\
\hline Thysanoessa gregaria G.O. Sars, 1883 & 1.609 & 0.609 & 36.36 \\
\hline Thysanoessa spp. & 3.400 & 1.287 & 36.36 \\
\hline Nematoscelis spp. & 0.677 & 0.256 & 29.55 \\
\hline Nematobrachion flexipes (Ortmann, 1893) & 0.332 & 0.126 & 29.55 \\
\hline Stylocheiron carinatum G.O. Sars, 1883 & 1.398 & 0.529 & 61.36 \\
\hline Stylocheiron affine Hansen, 1910 & 0.026 & 0.010 & 2.27 \\
\hline Stylocheiron suhmii G.O. Sars, 1883 & 2.726 & 1.032 & 47.73 \\
\hline Stylocheiron microphthalma Hansen, 1910 & 0.268 & 0.101 & 13.64 \\
\hline Stylocheiron abbreviatum G.O. Sars, 1883 & 1.379 & 0.521 & 34.09 \\
\hline Stylocheiron spp. & 3.107 & 1.176 & 52.27 \\
\hline
\end{tabular}


groups of sampling stations $(\mathrm{F}=1.623 ; p=0.001)$. Euphausia lucens (76\%), Stylocheiron carinatum (14\%), and Thysanopoda spp. (6\%) were the species responsible for the differences observed between the west and east sections of the transect (see Table SII). Overall abundance and frequency of occurrence of Euphausia species were highest at stations near Africa, while those of Thysanopoda species were highest at those near Brazil (Figure 3).

RDA analysis showed that the factor that most influenced euphausiid species distribution was sampling depth $\left(\mathrm{r}^{2}=0.118 ; \mathrm{F}=1.626 ; p=\right.$ $0.037)$, followed by salinity $\left(\mathrm{r}^{2}=0.087 ; \mathrm{F}=2.585\right.$; $p=0.017)$, temperature $\left(\mathrm{r}^{2}=0.105 ; \mathrm{F}=1.794 ; p=\right.$ $0.016)$, and chlorophyll- $a\left(\mathrm{r}^{2}=0.059 ; \mathrm{F}=3.399\right.$; $p=0.002$ ) (Figure 3). The sampling period was correlated with significant differences in species composition ( $\mathrm{F}=2.695 ; p=0.001)$; Euphausia recurva $(\mathrm{CI}=18 \%)$ had higher abundances in nighttime samples (Figure 3).

A total of 158 Thysanopoda specimens was recorded: 2 male T. astylata, 6 male T. aequalis, 3 T. pectinata, 2 T. monacantha, 2 T. tricuspida, and 1 T. egregia. Of the remaining specimens, 118 were identified only as Thysanopoda spp., and 24 were grouped into a $T$. aequalis / T. astylata complex because only mature males could be differentiated based on the morphology of the third thoracic leg (see Figure S2a, b); T. aequalis has a long flagellum-like spinal modification (see Figure S2c) of the dactyl and propod, and T. astylata lacks this styliform process (see Figure S2d).

Thysanopoda averaged 1.1 organisms 100 $\mathrm{m}^{-3}$ (Figure 4a), with greater abundances towards the western part of the Atlantic; a density of 20.7 organisms $100 \mathrm{~m}^{-3}$ was recorded near the Rio Grande Rise. Individuals of the Thysanopoda aequalis / T. astylata complex were collected only during the night at seven stations between $033^{\circ} 48.08^{\prime} \mathrm{W}$ and $003^{\circ} 20.94^{\prime} \mathrm{W}$, with densities never exceeding 3.3 organisms $100 \mathrm{~m}^{-3}$ (Figure $4 \mathrm{~b}$ ). Thysanopoda astylata males were recorded at stations $33\left(032^{\circ}\right.$ $\left.04.34^{\prime} \mathrm{W}\right)$ and $55\left(003^{\circ} 20.94^{\prime} \mathrm{W}\right)$ at depths down to 64 meters, with a maximum density of 0.3 organisms $100 \mathrm{~m}^{-3}$, while T. aequalis males were found at four stations (stations 39, 41, 46, and 55) with a maximum density of 0.6 organisms $100 \mathrm{~m}^{-3}$ in samples never exceeding 80 meters in depth.

Of the remaining Thysanopoda species, only furcilia stages were found. Thysanopoda pectinata was found at three stations (stations 62, 71, and 75; Figure 4b) during day and night hours in samples from down to 92 meters, with 0.7 to 1.1 organisms $100 \mathrm{~m}^{-3}$. Thysanopoda monacantha was also found in samples collected in both periods at stations 34 and 35 at depths down to $62 \mathrm{~m}$, with densities up to 0.3 organisms $100 \mathrm{~m}^{-3}$, while $T$. tricuspida was found only at station 39, during the night at depths shallower than 55 meters, at an abundance of 0.4 organisms $100 \mathrm{~m}^{-3}$. Only a single furcilia Thysanopoda egregia was found at station 67 during daylight hours, corresponding to 0.5 organisms $100 \mathrm{~m}^{-3}$ (Figure 4b).

\section{DISCUSSION}

There was an obvious gradient of temperature along the studied profile, with higher temperatures towards the Brazilian coast and lower ones near the African coast. The South Atlantic is influenced by two major currents: the relatively warm and salty Brazil current to the west, and the colder and less saline Benguela current to the east. The eastern periphery of the Benguela current is characterized by an upwelling area with pronounced lower surface temperature (Shannon and Nelson 1996, Hutchings et al. 2009). The presence of cold waters over the shelf on the South African coast in this study is an indication of upwelled waters causing the surface temperature values found.

Higher euphausiid abundances were associated with the colder waters found on the eastern side of the transect. Overall species composition and abundances on the eastern side were in agreement 


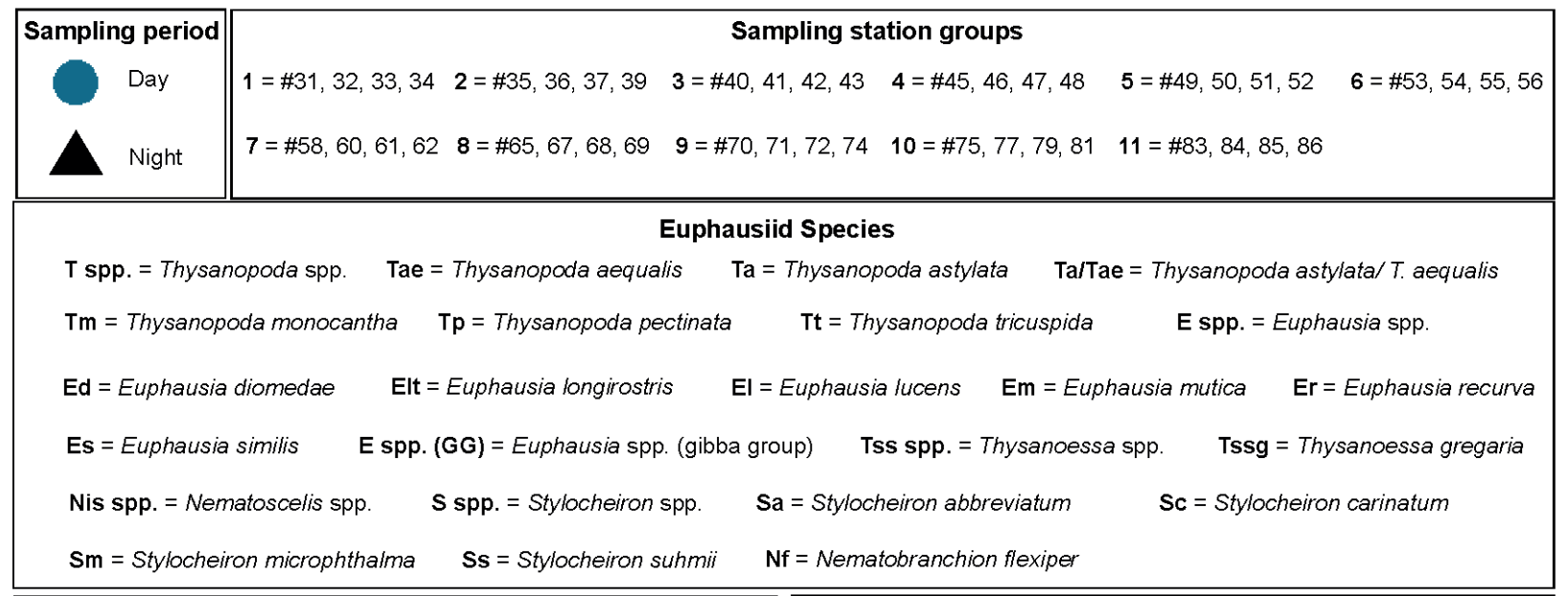
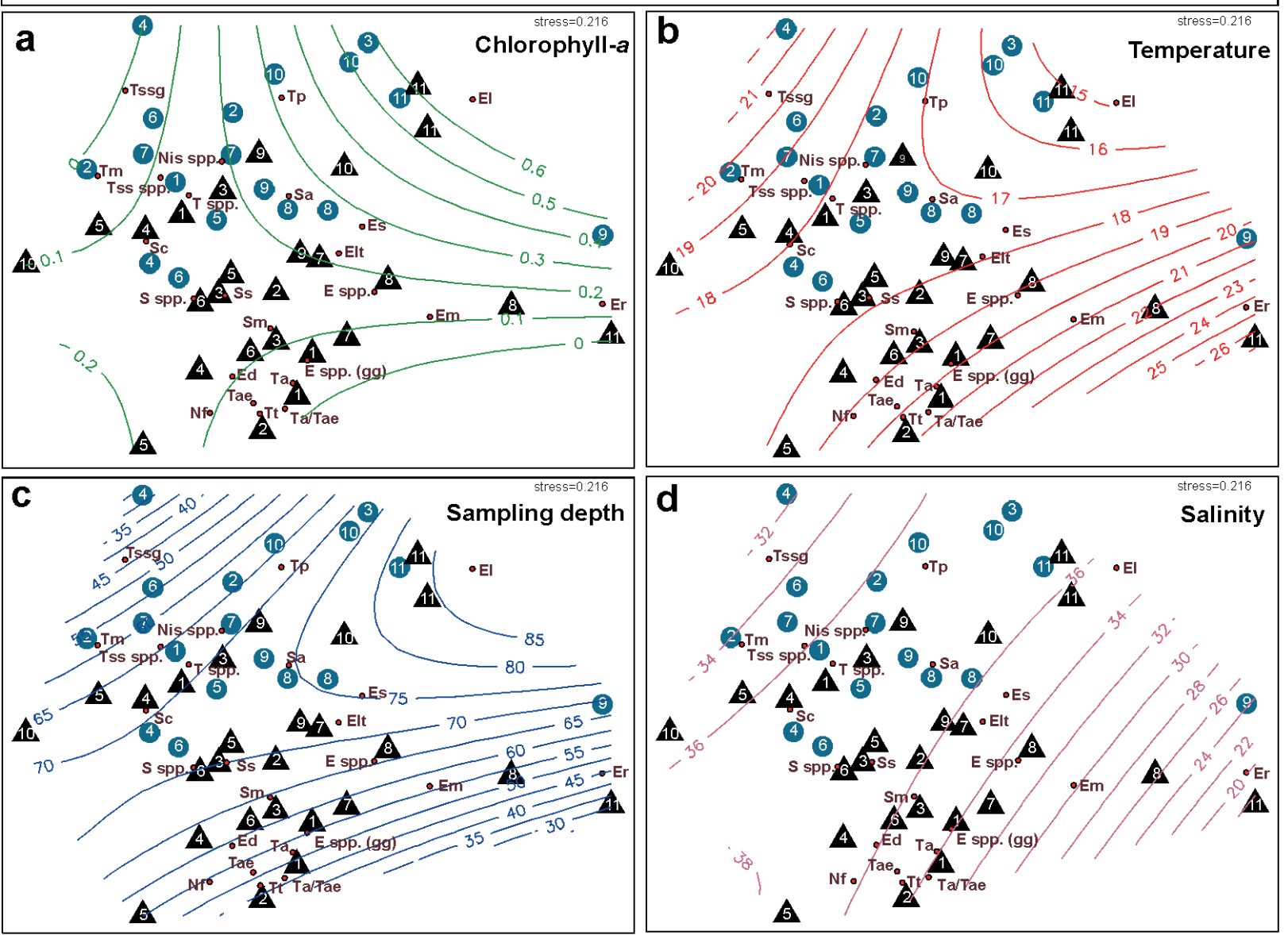

Figure 3 - MDS ordination based on Bray-Curtis similarity and euphausiid species composition (44 samples) from a Brazil-Africa cruise and different environmental variables: (a) chlorophyll- $a$; (b) temperature; (c) sampling depth; (d) salinity. 

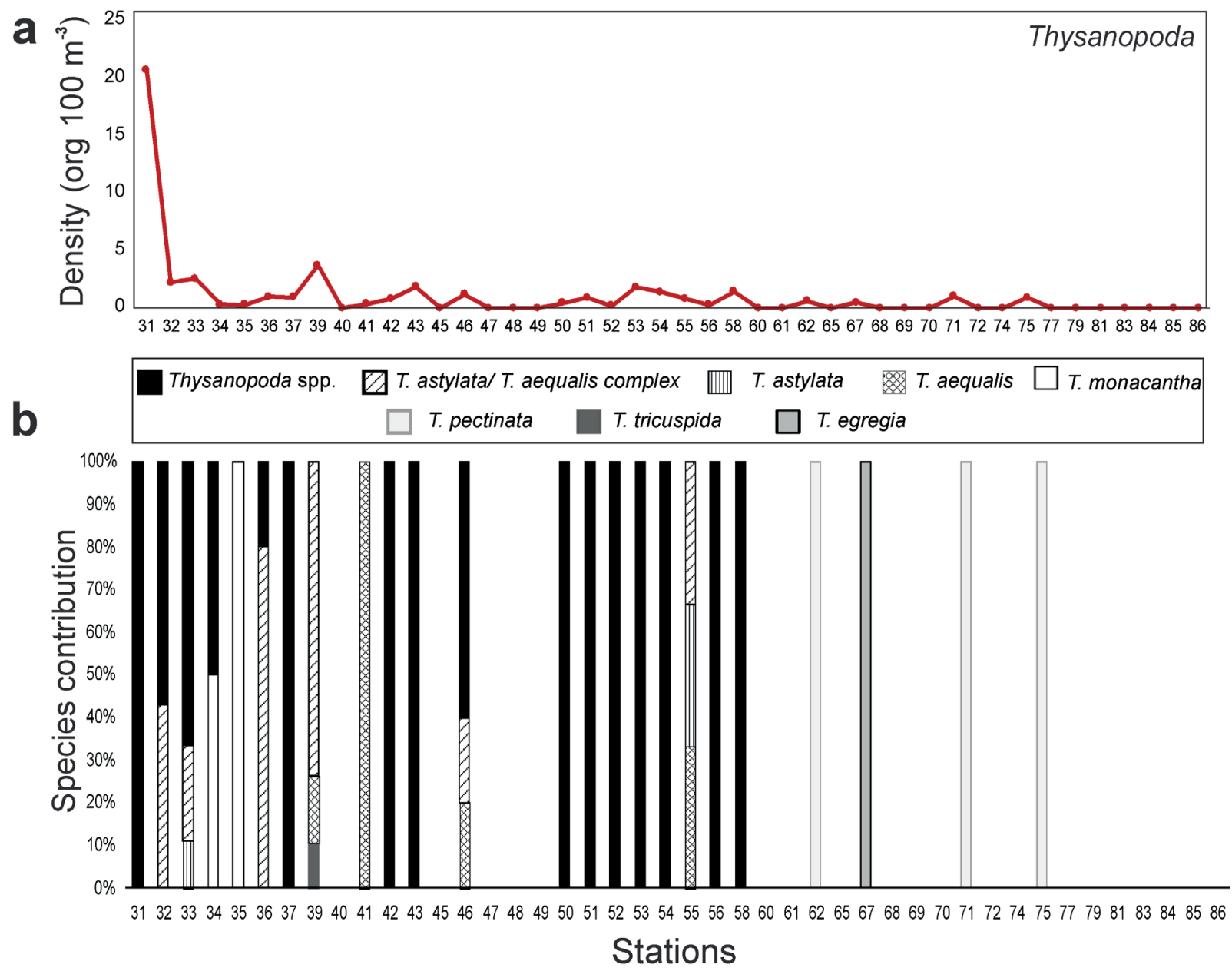

Figure 4 - (a) Thysanopoda total density (organisms $100 \mathrm{~m}^{-3}$ ), and (b) percentage contribution of each Thysanopoda species at each station along the $30^{\circ} \mathrm{S}$ transect through the South Atlantic Ocean.

with what has been published previously, with Euphausia species being dominant in the Benguela upwelling system. This region is one of the most productive coasts of the world's oceans (Hutchings 1992), where euphausiids and copepods can dominate the mesozooplankton (Ekau et al. 2010). There were also trends in overall distribution, like an increase in the abundance of Euphausia species near the African continent, while Thysanopoda species were more abundant closer to Brazil. According to Pillar et al. (1992) and Werner and Buchholz (2013), in the coastal upwelling of Africa, Euphausia lucens, E. americana, E. gibboides, E. hanseni, E. recurva, Nyctiphanes capensis, and $N$. megalops have the highest biomass and abundances. However, of these only E. lucens and E. recurva were recorded in the current work.

Our data probably underestimated euphausiid abundances, as we only sampled the upper epipelagic stratum with a small ring net fitted with a fine mesh, which was most suitable for sampling smaller stages (i.e., furcilia, calyptopis, and nauplii) that cannot avoid the net. For this reason, the adult euphausiid distribution presented in this study should be interpreted with caution, as the adults are strong migrators (Barange 1990) and could avoid capture by net. Although our net was not the proper gear to fully sample this community, 
the results presented here give important insight into the near-surface distribution of these animals and could corroborate some studies that indicate plankton are dispersed from the Indian Ocean to the Atlantic through transport along the African coastline rather than through the Drake passage (D’Amato et al. 2008).

According to Robledo and Mujica (1999), temperature and salinity are the main environmental variables that affect the distribution patterns (vertical and horizontal) of euphausiids, and in the current work the species found were within the known temperature and salinity values reported for them (Antezana and Brinton 1981).

Thysanopoda pectinata, T. monacantha, and T. tricuspida are mesopelagic species, with adults usually restricted to thermocline depths (Brinton et al. 1999). In the South Atlantic, these species occur from 0 to $35^{\circ} \mathrm{S}$, with $T$. pectinata being reported at $0-30^{\circ} \mathrm{S}, T$. monacantha at $20-35^{\circ} \mathrm{S}$ and $T$. tricuspida at $0-35^{\circ} \mathrm{S}$ (Brinton et al. 1999, Gibbons et al. 1999). In the present study, all three species were within their reported ranges, with $T$. pectinata being found only towards the eastern side of the transect, while T. monacantha and T. tricuspida were found on the western side, near Rio Grande Rise. Only a single Thysanopoda egregia furcilia was found bearing the characteristic ripple marks on the posterior and lateral parts of the carapace, the short sixth pleomere, and big eyes (Brinton 1962, 1975, Brinton et al. 2013). According to Gibbons et al. (1999), T. egregia is a bathypelagic species usually associated with seamounts (Siegel 2015). In the present study, it was collected during the day at a station close to the Walvis Ridge at a tow down to $96 \mathrm{~m}$, which increases the known vertical range of this species; it was previously caught only at depths below $300 \mathrm{~m}$ (Brinton et al. 1999).

According to Brinton (1975) and Brinton et al. (1999), T. aequalis and T. astylata usually co-occur in parts of the Pacific and the Indian Ocean, but not in the Atlantic, where only T. aequalis was previously reported between $50{ }^{\circ} \mathrm{N}$ and $35^{\circ} \mathrm{S}$. Considering that, we could infer the possibility of transport of this species from the Indo-Pacific region into the Atlantic through the Agulhas Leakage (Richardson 2007). The "absence" of Thysanopoda in the Atlantic could be associated with the presence of environmental barriers (Barange et al. 1992) or, more likely, with poor sampling, lack of diagnostic features, or the scarcity of basin-wide studies in the Southern Atlantic, along with the difficulties in identifying these species in plankton samples. In South Atlantic waters, basin-wide studies of the distribution and abundance of euphausiids are lacking, and most current knowledge is based on presence/absence data from historical literature such as $19^{\text {th }}$ century treatises and expedition reports (Gibbons et al. 1999); quantitative data are generally limited to studies conducted after the second half of the $20^{\text {th }}$ century in coastal zones in the western South Atlantic and the eastern South Atlantic (see Table SIII).

According to Constanzo and Guglielmo (1976), identification of T. astylata in plankton samples requires the presence of mature adult males with the third leg undamaged by the sampling process. Luckily, some adult male specimens of Thysanopoda aequalis and T. astylata found during the present study were in good condition, each with at least one of their third thoracic legs intact. The two adult male specimens of $T$. astylata found in this study were collected at stations 33 $\left(032^{\circ} 04.34^{\prime} \mathrm{W}\right)$, near the Rio Grande Rise, and $55\left(003^{\circ} 20.94^{\prime} \mathrm{W}\right)$ (Figure 1); both showed the characteristics described by Brinton (1975), Baker et al. (1990), and Brinton et al. (1999). Samples at both of those stations were taken at night, which could justify these individuals' presence at relatively shallow depths (Table SIII); Brinton et al. (1999) reported that adults can be found at depths of 25-200 m after dusk. The current study could not verify morphological differences between Pacific/ Indian Ocean and Atlantic specimens, which could 
exclude the possibility of allopatric separation; confirmation will require molecular tools.

Based on our results, we believe that the absence of records of Thysanopoda minyops and T. spinicaudata in the South Atlantic is also related to the lack of samples from the deeper strata of the central area of the South Atlantic, since the first one is an abyssopelagic (4000-6000 $\mathrm{m}$ ) species and the second is bathypelagic (1000-4000 $\mathrm{m}$ ) and reported in other oceans (Central North Pacific and Indian) (Brinton 1987, Brinton et al. 1999, Siegel 2015).

\section{CONCLUSIONS}

i) A total of 19 euphausiid species belonging to six genera were recorded along a transect in the South Atlantic Ocean at $30^{\circ} \mathrm{S}$;

ii) Overall euphausiid abundances increase towards Africa. Euphausia species are more common in the eastern Atlantic (Africa), while Thysanopoda species are more common in the western Atlantic (Brazil);

iii) Thysanopoda averaged 1.1 organisms $100 \mathrm{~m}^{-3}$, and in the western part of the Atlantic (near Rio Grande Rise) had a density of 20.7 organisms $100 \mathrm{~m}^{-3}$;

iv) Thysanopoda egregia was caught in samples collected down to $96 \mathrm{~m}$, which increases the vertical range for this species.

v) The present study is the first record of Thysanopoda astylata in Atlantic waters. Until this study, 60 euphausiid species were described in South Atlantic waters (Gibbons et al. 1999). Since there is no previous record of T. astylata, the number of described euphausiid species in the South Atlantic is now 61.

\section{ACKNOWLEDGMENTS}

The authors thanks Tatiana Ávila, Alessandro Cardoso, and crew of the Oceanographic vessel Cruzeiro do Sul of the Brazilian Navy for collection of the zooplankton samples.

\section{AUTHOR CONTRIBUTIONS}

Erik Muxagata contributed with sampling design, samples analyses, writing, reviewing and editing; Carla Neme Barbosa contributed with samples analyses and writing; Vanessa Ochi Agostini contributed with data analyses, writing, reviewing and editing.

\section{REFERENCES}

ANTEZANA T AND BRINTON E. 1981. Euphausiacea. In: Boltovskoy D (Ed), Atlas del Zooplancton del Atlántico Sudoccidental y métodos de trabajo con el zooplancton marino. Pub Esp INIDEP, Mar del Plata, Argentina, p. 681698.

BAINBRIDGE V. 1972. The zooplankton of Gulf of Guinea. Bull Mar Ecol 8(1): 61-97.

BAKER A DE C, BODEN BP AND BRINTON E. 1990. A practical guide to the Euphausiids of the world. British Museum (Natural History), London, $96 \mathrm{p}$.

BARANGE M. 1990. Vertical migration and habitat partitioning of six euphausiids species in the northern Benguela upwelling systems. J Plankton Res 12: 12231237.

BARANGE M, GIBBONS MJ AND CAROLA M. 1991. Diet and feeding of Euphausia hanseni and Nematoscelis megalops (Euphausiacea) in the Northern Benguela Current-ecological significance of vertical space partitioning. Mar Ecol Prog Ser 73: 173-181.

BARANGE M AND PILLAR SC. 1992. Cross-shelf circulation, zonation and maintenance mechanisms of Nyctiphanes capensis and Euphasia hanseni in the northern Benguela upwelling system. Cont Shelf Res 12: 1027-1042.

BARANGE M, PILLAR SC AND HUTCHINGS L. 1992. Major pelagic borders of the Benguela upwelling system according to euphausiid species distribution. S Afr J Marine Sci 12: 3-17.

BODEN BP. 1961. Euphausiacea (Crustacea) from tropical West Africa Atl Rep 6: 251-262.

BRINTON E. 1962. The distribution of Pacific euphausiids. Bull Scripps Inst Oceanogr 8: 51-270.

BRINTON E. 1975. Euphausiids of the south east Asian waters. Naga report. Scientific Results of Marine Investigations of the South China Sea and the Gulf of Thailand 4: 1-287.

BRINTON E AND ANTEZANA T. 1984. Structures of swarming and dispersed populations of krill (Euphausia superba) in Scotia Sea and South Shetland waters during January- March 1981, determined by Bongo nets. J Crustacean Biol 4: 45-66. 
BRINTON E, OHMAN MD, TOWNSEND AW, KNIGHT MD AND BRIDGEMAN AL. 1999. Euphausiids of the world ocean. World Biodiversity Database CD-ROM series. ETI Expert Center for Taxonomic Identification.

BRINTON E, TOWNSEND AW, KNIGHT MD AND OHMAN MD. 2013. Development of Thysanopoda egregia (Euphausiacea) furciliae and early juvenile. J Crustacean Biol 33: 244-252.

COSTANZO G AND GUGLIELMO L. 1976. Diagnostic value of the thelycum in Euphausiids, I. Mediterranean species (first note). Crustaceana 31(1): 45-53.

CURTOLO LM, DADON JR AND MAZZONI HE. 1990. Distribution and abundance of euphausiids off Argentina in spring 1978. Nerítica 5: 1-14.

D'AMATO ME, HARKINS GW, DE OLIVEIRA T, TESKE PR AND GIBBONS MJ. 2008. Molecular dating and biogeography of the neritic krill Nyctiphanes. Mar Biol 155: 243-247.

DZIK J AND JAZDZEWSKI K. 1978. The euphausiid species of the Antarctic region. Pol Arch Hydrobiol 25: 589-605.

EKAU W, AUEL H, PÖRTNER H-O AND GILBERT D. 2010. Impacts of hypoxia on the structure and processes in pelagic communities (zooplankton, macro-invertebrates and fish). Biogeosciences 7: 1669-1699.

ENDO Y, IMASEKI T AND KOMAKI Y. 1986. Biomass and population structure of Antarctic Krill (Euphausia superba Dana) collected during SIBEX II Cruise of R.V. Kaiyo Maru. Mem Natl Inst Polar Res, Spec issue 44: 107-117.

FREIRE AS. 1991. Variação espaço-temporal do zooplâncton e das espécies de Euphausiacea (Crustacea) ao largo da costa do Brasil (23 - $\left.18^{\circ} \mathrm{S}-41-28^{\circ} \mathrm{W}\right), 137$ p. Dissertação de Mestrado. Universidade de São Paulo, São Paulo, SP. (Unpublished).

GIBBONS MJ. 1997. Pelagic biogeography of the South Atlantic Ocean. Mar Biol 129: 757-768.

GIBBONS MJ, BARANGE M AND HUTCHINGS L. 1995. The zoogeography and diversity of euphausiids around southern Africa. Mar Biol 123: 257-268.

GIBBONS MJ, SPIRIDONOV VA AND TARLING GA. 1999. Euphausiacea. In: Boltovskoy D (Ed), South Atlantic Zooplankton. Backhuys Publishers. Leiden, The Netherlands, p. 1241-1279.

GORRI C. 1995. Distribuição espaço-temporal e estrutura populacional de Euphausiacea (Crustacea) na região do extremo Sul do Brasil (31 $\left.{ }^{\circ} 40^{\prime} \mathrm{S}-33^{\circ} 45^{\prime} \mathrm{S}\right), 124$ p. Dissertação de Mestrado. Fundação Universidade do Rio Grande, Rio Grande, RS. (Unpublished).

HUTCHINGS L. 1992. Fish harvesting in a variable, productive environment-searching for rules or searching for exceptions? In: Payne AIL, Brink KH, Mann KH et al. (Eds), Benguela Trophic Functioning. S Afr J Mar Scim 12: 297-318.
HUTCHINGS L ET AL. 2009. The Benguela Current: An ecosystem of four components. Progress in Oceanography 83: $15-32$.

LANSAC-TÔHA FA. 1981. Sistemática e distribuição geográfica de Euphausiacea (Crustacea) ao largo das costas sul do Brasil (Lat. $\left.22^{\circ} \mathrm{S}-30^{\circ} \mathrm{S}\right), 109$ p. Dissertação de Mestrado. Universidade de São Paulo (USP), São Paulo. (Unpublished).

LETESSIER TB, COX MJ AND BRIERLEY AS. 2009. Drivers of euphausiid species abundance and numerical abundance in the Atlantic Ocean. Mar Biol 156(12): 25392553.

LETESSIER TB, FALKENHAUG T, DEBES H, BERGSTAD OA AND BRIERLEY AS. 2011. Abundance patterns and species assemblages of euphausiids associated with the Mid-Atlantic Ridge, North Atlantic. J Plankton Res 33(10): 1510-1525.

MARTIN JW AND DAVIS GE. 2001. An updated classification of the recent crustacea. Contributions in Science 39: 1-124.

MAUCHLINE J. 1971. Euphausiacea larvae. Fiches d'Identification du Zooplancton. Fiche 135/137: 1-16.

MAUCHLINE J. 1980. Advances in marine biology (Volume 18) - The biology of mysids and euphausiids. Academic Press, London, $681 \mathrm{p}$.

MAUCHLINE J. 1984. Synopses of the British Fauna no. 30: Euphausiid, Stomatopod and Leptostracan crustaceans. E.J. Brill, Publishing Company, Leiden, The Netherlands, $91 \mathrm{p}$.

MAUCHLINE J AND FISHER LR. 1969. Advances in marine biology (Volume 7): The biology of Euphausiids. Academic Press, London, 454 p.

MENEZES BS. 2007. Variação espaço-temporal e nictemeral de euphausiacea (Crustacea) ("Krill”) no arquipélago de São Pedro e São Paulo: inverno e primavera de 2003. Disponível em: https://repositorio.ufsc.br

MIKKELSEN PM. 1987. The Euphausiacea of eastern Florida (Crustacea: Malacostraca). Proc Biol Soc Wash 100(2): 275-295.

MONTÚ M. 1977. Eufausidos de la plataforma Argentina y adyacencias I. Distribucion estacional en el sector Patagonico. Ecosur 4(8): 187-225.

MONTÚ M. 1982. Reproducción y ciclos de vida en cuatro especies de Eufáusidos Patagônicos (Crustacea, Eucarida). Arq Bio Tecnol 25: 247-259.

MONTÚ M AND CORDEIRO TA. 1986. Estudo do zooplâncton coletado durante a primeira expedição brasileira à Antártica pelo NApOc "Barão de Teffé". Nerítica 1: 85-133.

MONTÚ M AND OLIVEIRA IR. 1986. Zooplanktonic associations, throphic relations and standing stock of krill and other groups of the community near Elephant Island (February - March 84/85). Nerítica 1: 111-135. 
MONTÚ MA, GLOEDEN IM, RESGALLA JR C AND LOUREIRO FERNANDES LF. 1994. Krill populations in the Bransfield strait and neighbouring areas during the summers of 1983, 1984, 1985 and 1987. Nauplius 2: 107121.

PILLAR SC, ARMSTRONG DA AND HUTCHINGS L. 1989. Vertical migration, dispersal and transport of Euphausia lucens in the southern Benguela Current. Mar Ecol ProgSeries 53: 179-190.

PILLAR SC, STUART V, BARANGE M AND GIBBONS MJ. 1992. Community structure and trophic ecology of euphausiids in the Benguela ecosystem. S Afr J Marine Sci 12: 393-409.

RAMIREZ FC. 1971. Eufáusidos de algunos sectores del Atlántico sudoccidental. Physis Seccion A: Los Oceanos y sus Organismos 30: 105-114.

RICHARDSON PL. 2007. Agulhas leakage into the Atlantic estimated with subsurface floats and surface drifters. Deep Sea Res Part I 54: 1361-1389.

ROBLEDO OB AND MUJICA AR. 1999. Eufáusidos de Isla de Pascua. Investig Mar 27: 65-72.

SCHNETZER A AND STEINBERG DK. 2002. Active transport of particulate organic carbon and nitrogen by vertically migrating zooplankton in the Sargasso Sea. Mar Ecol Prog Ser 234: 71-84.

SHANNON LV AND NELSON G. 1996. The Benguela: Large Scale Features and Processes and System Variability. In: Wefer G, Berger WH, Siedler D and Webb D (Eds), The South Atlantic: Present and Past Circulation. Springer, Berlin, Heidelberg, p. 163-210.

SIEGEL V. 2015. World Euphausiacea database. Accessed through: World Register of Marine Species. Available at: http://www.marinespecies.org.

SIEGEL V AND WATKINS JL. 2016. Distribution, Biomass and Demography of Antarctic Krill, Euphausia superba. Biology and Ecology of Antarctic Krill, p. 21-100.

STEEDMAN HF. 1976. V - Aldehydes - 1. General and applied data on formaldehyde fixation and preservation of marine zooplankton. In: Steedman HF (Ed), Monographs on oceanographic methodology No 4 - Zooplankton fixation and preservation. The UNESCO Press. Paris, p. 103-154.

WERNER T. 2012. Trophic positioning, diel vertical migration and physiological constraints in euphausiid species of the Namibian upwelling system - Implications for krill as indicator of environmental conditions, 167 p. Ph.D. Thesis. Universität Hamburg, Hamburg.

WERNER T AND BUCHHOLZ F. 2013. Diel vertical migration behaviour in Euphausiids of the Northern Benguela Current: Seasonal adaptations to food availability and strong gradients of temperature and oxygen. J Plankton Res 35: 792-812.

\section{SUPPLEMENTARY MATERIAL}

Table SI - Zooplankton data for the South Atlantic Ocean during the First Transatlantic Commission (Brazil-Africa) in 2009, showing the stations, sampling dates, sampling time, coordinates, local ocean depth and sampling depth.

Table SII - SIMPER test to identify the contribution index (CI) of euphausiid species between sampling stations toward the western (Brazil) and eastern (Africa) sides of the South Atlantic Ocean.

Table SIII - Main literature about euphausiid distribution in South Atlantic waters.

Figure S1 - Sea surface temperature and temperature vertical profile along the $30^{\circ} \mathrm{S}$ transect through the South Atlantic Ocean.

Figure S2 - Adult males of (a) Thysanopoda astylata and (b) T. aequalis. Details show (c) the dactylus of the third thoracic leg of T. astylata, and (d) the long flagellum spine modification of the dactylus of the third thoracic leg of T. aequalis. 